Russell, R. S., and R. P. Martin. 1949. Use of radioactive phosphorus in plant nutritional studies. Nature 163: $71-72$.

SAX, K. 1940. An analysis of X-ray induced chromosome aberrations in Tradescantia. Genetics 25: 4l-68.
Sharman, B. C. 1945. Leaf and bud initiation in the Gramineae. Bot. Gaz. 106: 269-289.

Smith, G. F., And H. Kersten. 1941. Root modifications induced in Vicia faba by irradiating dry seeds with soft X-rays. Plant Physiol. 16: 159-170.

\title{
STUDIES IN THE GENUS PLEOSPORA. VI ${ }^{1}$
}

\author{
Lewis E. Wehmeyer
}

IN A PREVIOUS PAPER (Wehmeyer, 1952b), it was pointed out that the two types of septation characteristic of the leptosphaeroid and vulgaris series in the genus Pleospora tend to converge above the five-septate level, and that very often both types of septation appear in the same spore. In that paper, the species with spores showing an asymmetric septation were arbitrarily taken as representing the leptosphaeroid series and discussed as such.

The present paper is to deal with those species which show a similar but symmetric septation in the ascospore, and which present a more or less parallel group.

The species of Pleospora with five-septate spores of the vulgaris type have already been considered (Wehmeyer, 1952a). There are some five recognizable species (known to the writer) which represent the seven-septate condition, which arises by the insertion of a secondary transverse septum in each of the end cells of a five-septate spore. All of these species differ from $P$. trevoicola, previously discussed (Wehmeyer, 1952b), in the more constantly symmetric spores.

Three of these species occur on monocotyledons. $P$. punctata, on Scirpus, has small perithecia on limited gray spots, and ascospores which are somewhat rounded above and asymmetric in form. $P$. thurgoviana, on Typha, has larger perithecia on extended grayish areas of the stem, and more symmetric spores. P. heleocharidis, on grasses and sedges, shows no discolored areas on the stem and has spores with more sharply tapered ends and less constriction at the septa.

On dicotyledons, $P$. tomentosa differs in the densely tomentose perithecia and $P$. henningsiana has large perithecia of the type found in woodinhabiting species, and has large, more cylindric ascospores.

The transition to the nine-septate condition is seen in $P$. pleosphaerioides, the ascospores of which often show a tertiary septum in each of the end cells. Its perithecia are strongly setose.

In $P$. minor there are occasional septa in addition to the typical seven, showing this same tendency in a group with somewhat different form of ascospore; i.e., with more rounded ends and more

1 Received for publication October 27, 1951.

Papers of the Department of Botany of the University of Michigan No. 962. definitely inequilateral or curved. In $P$. alismatis, with similar spores, the nine-septate condition is fixed. In $P$. rubicunda the ends of the ascospores are still more broadly rounded and the spores may become eleven-septate, by the formation of secondary vulgaris septa in four of the central cells.

In $P$. moravica and $P$. saponariae, this type of septation is well illustrated, for there is great variability in the septation of spores of varying maturity showing this progression. The secondary vulgaris type of septation may occur in any of the four central cells of the spores of these species, but this is often delayed, or these septa are fainter than the transverse septa first laid down. $P$. moravica has a spore form similar to $P$. abscondita and differs from that species chiefly in the more symmetric mode of laying down the septa in the spore. $P$. saponariae has larger spores approaching those of $P$. rubicunda in form.

In table 1, data are given concerning host, and spore, ascus and perithecial measurements of the individual collections discussed. It is interesting to note that nearly all these species, except $P$. henningsiana and $P$. saponariae, which are distinctive in other respects, have spores within a very similar size range, i.e., 25-40 $\mu$, which again corresponds to the size range previously chosen for $P$. herbarum. This is the most variable range of Pleospora spores, and details of form and septation must necessarily be carefully considered.

Collections are referred to throughout this paper by number. The data for these numbered collections are given at the end of the paper.

Pleospora punctata Wehm. in Lloydia 9: 214. 1946.-Inasmuch as this species has already been described by the writer, its description will not be repeated here. The spores (fig. 1) differ from those of $P$. trevoicola in being larger $(26-30 \times 10$ $14 \mu$ ), more asymmetric in form and more constantly seven-septate. The perithecia are small $(120-150 \mu)$ and on small, limited, grayish-colored areas.

Collections: 272 (type) on Scirpus from Wyoming.

Pleospora thurgoviana Wegelin in Mitt. Thurgauischer Naturf. Ges. 12: 9. 1896.-Perithecia $200-4,00 \times 200-250 \mu$, globose to somewhat depressed, immersed beneath the somewhat grayish discolored surface of the stem; grayish areas 3-4 

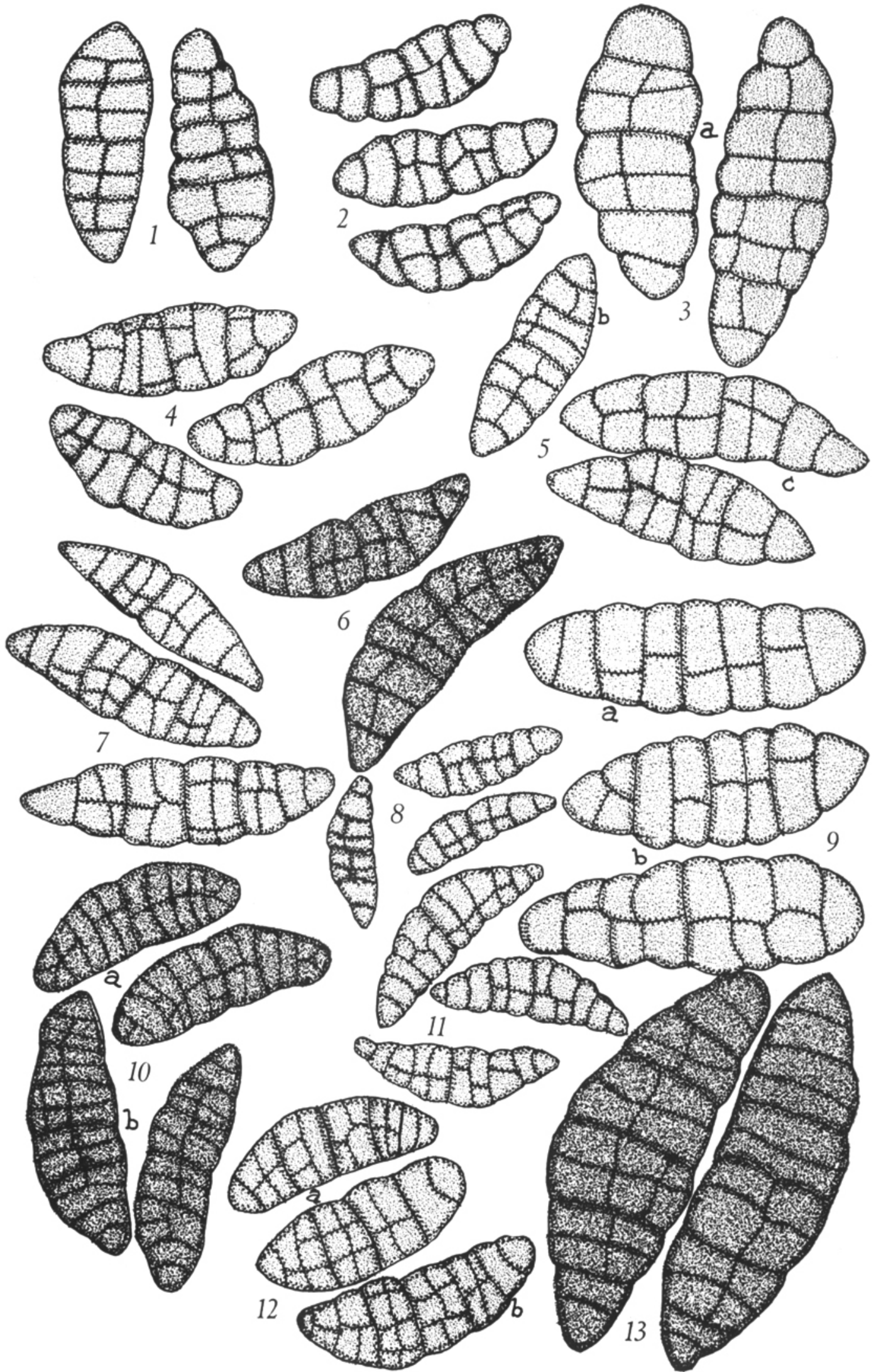
TABLE I. Comparison of host, spore, ascus and perithecial measurements of species discussed.

\begin{tabular}{|c|c|c|c|c|}
\hline Coll. No. & Host & Spores & Asci & Perithecia \\
\hline \multirow{2}{*}{\multicolumn{5}{|c|}{$\begin{array}{c}\mu \\
\text { Pleospora punctata }\end{array}$}} \\
\hline & & & & \\
\hline 272 & Scirpus & $26-30(33) \times 10-14$ & $75-85 \times 21-25$ & $120-150$ \\
\hline \multicolumn{5}{|c|}{ Pleospora thurgoviana } \\
\hline 271 & - & $26-30 \times 9-11$ & $90-140 \times 13-21$ & $300-400$ \\
\hline \multicolumn{5}{|c|}{ Pleospora heleocharidis } \\
\hline 330 & Calamagrostis & $25-35 \times 9-12.5$ & $90-125 \times 21-26.5$ & $350-400$ \\
\hline 255 & Grass & $28.5-35 \times 10-11$ & $115-140 \times 23-25$ & 300 \\
\hline 353 & Aira & $32-39 \times 10-11$ & $115-160 \times 23-26$ & $200-350$ \\
\hline 669 & Heleocharis ... & $34-38 \times 10-11$ & $80-85 \times 28-31$ & \\
\hline \multicolumn{5}{|c|}{ Pleospora tomentosa } \\
\hline 277 & Herbs & $23-30 \times 8.5-10.5$ & $100-140 \times 13-20$ & $250-350, \mathrm{~T}$ \\
\hline 280 & Castilleja & $28-35 \times 10.5-12.5$ & $85-108 \times 19-23$ & $300-400, T$ \\
\hline 278 & Rudbeckia & $26-35 \times 9-10$ & $78-95 \times 20$ & $300-350, \mathrm{~T}$ \\
\hline \multicolumn{5}{|c|}{ Pleospora pleosphaerioides } \\
\hline 273 & Gilia & $32-39 \times 9.5-12$ & $160-200 \times 17-19$ & $400-500, \mathrm{~S}$ \\
\hline \multicolumn{5}{|c|}{ Pleospora hennungsiana } \\
\hline 283 & Stems ... & $39-44 \times 12-14$ & $110-160 \times 20-35$ & $500-700$ \\
\hline 284 & - & $40-44 \times 12-14$ & $140-160 \times 26-35$ & $700-900$ \\
\hline \multicolumn{5}{|c|}{ Pleospora moravica } \\
\hline 282 & Salsola & $23-26(33) \times 8-10$ & $106-140 \times 12.5-14$ & $350-500$ \\
\hline 489 & Vitis & $26.5-30 \times 9-10$ & $135-150 \times 14-21$ & $350-800$ \\
\hline 286 & Salix & $26-35 \times 8.5-9.5$ & $140-175 \times 16-21$ & $500-700$ \\
\hline \multicolumn{5}{|c|}{ Pleospora saponariae } \\
\hline 497 & Saponaria & $48-57 \times 16-18$ & $124 \times 35$ & $100-150$ \\
\hline \multicolumn{5}{|c|}{ Pleospora minor } \\
\hline 276 & Grass & $21.5-26.5 \times 7-7.4$ & $85-170 \times 14-19$ & 250 \\
\hline \multicolumn{5}{|c|}{ Pleospora alismatis } \\
\hline 285 & Alisma & $26-33 \times 7-9.5$ & $85-110(160) \times 12.5-18$ & $300-500$ \\
\hline \multicolumn{5}{|c|}{ Pleospora rubicunda } \\
\hline 346 & Brachypodium & $23-27(30) \times 8.5-10$ & $115-130 \times 21.5$ & $250-350$ \\
\hline 287 & Aconitum & $26-32 \times 9-11$ & $160 \times 21-25$ & $250-350$ \\
\hline 288 & Stems & $27-30 \times 8-9$ & $125-150 \times 14-19$ & $200-400$ \\
\hline 289 & Aconitum & $30-39 \times 9-12$ & $140 \times 21$ & $300-400$ \\
\hline 290 & Aconitum & $32-37 \times 11-13$ & $90-110 \times 21$ & $250-400$ \\
\hline \multicolumn{5}{|c|}{ P. rubicunda var. americana } \\
\hline 526 & Pedicularis & $30-38 \times 11-12.5$ & $140-160 \times 21-26$ & $250-300$ \\
\hline 525 & Potentilla & $32-37 \times 12.5-15$ & $160-180 \times 16-21$ & 400 \\
\hline
\end{tabular}

cm. in extent; erumpent as scattered papillate ostioles; wall $20-40 \mu$ thick, of dark brown parenchyma above, thinner and lighter colored below.

Asci clavate, with a claw-like base and a slightly thickened wall, becoming more elongate at matur- ity, 90-140 $\times 13-31 \mu$, imbedded among numerous interthecial strips.

Spores (fig. 2) biseriate to overlapping uniseriate, fusoid-cylindric to oblong-ellipsoid, mostly seven-septate, red-brown, symmetric, inaequilateral

Fig. 1-13.-Fig. 1. Ascospores from the type collection (272) of Pleospora punctata Wehm.-Fig. 2. Ascospores from the type collection (271) of Pleospora thurgoviana Wegelin.-Fig. 3. Ascospores from the type collection (669) of Pleospora heleocharidis Karst.-Fig. 4. Ascospores from the type collection (278) of Pleospora tomentosa Wehm.Fig. 5. Ascospores of Pleospora heleocharidis Karst., from collection No. 330 (b) and No. 353 (c).-Fig. 6. Ascospores from the type collection (273) of Pleospora pleosphaerioides Wehm.-Fig. 7. Ascospores from the type collection (286) of Pleospora moravica (Petr.) comb. nov.-Fig. 8. Ascospores from the type collection (276) of Pleospora minor sp. nov.-Fig. 9. Ascospores of Pleospora henningsiana Ruhl., Jahn \& Paul, from collections No. 283 (a) and No. 284 (b).-Fig. 10. Ascospores of Pleospora rubicunda Niessl, from collection No. 287 (a) and No. 288 (b).Fig. 11. Ascospores from the type collection (285) of Pleospora alismatis E. \& E.-Fig. 12. Ascospores of Pleospora rubicunda var. americana var. nov., from collection No. 525 (a) and the type collection, No. 526 (b).-Fig. 13. Ascospores from the type collection (497) of Pleospora saponariae (Frag.) comb. nov. 
or somewhat curved, slightly constricted at the septa, ends bluntly rounded, $26-30 \times 9-11 \mu$.

Collections: 271 (type) on Typha from Switzerland.

This description is taken from what is apparently type material, although the spores were originally given as " $35-40 \times 10-14$, rarely $26 \times 10 \mu$." Notations on the packet state that it belongs in "Pleospora punctiformis" and in "Clathrospora," but no indication of a clathrate condition of the spores was seen. This species differs from $P$. punctala in the larger perithecia and larger discolored areas and in the ascospores being red-brown in color, more symmetric in form and having greater constrictions at the secondary septa.

Pleosfora heleocharidis Karst. in Symbolae Mycol. Fennicam 2: 72. 1874.-Perithecia 200$400 \mu$ in diameter, globose or somewhat depressed, often appearing on the surface as small circular black spots with a central, erumpent, papillate ostiole; wall about $30 \mu$ thick, parenchymatic.

Asci clavate, with thickened walls, base claw-like, 80-140 $\times 21-31 \mu$.

Spores (fig. 3, 5) biseriate, fusoid-ellipsoid, sevenseptate, yellow-brown, symmetric or slightly broader above, straight to inaequilateral or slightly curved, constricted at the central septum and sometimes slightly so at the other septa, ends mostly rather acutely tapered, or sometimes bluntly rounded, two central cells usually with vulgaris type secondary septa, both end cells with secondary transverse septa, $25-44 \times 9-12 \mu$.

Collections: $330,353,355,669$ (type) ; on Heleocharis, Aira, Calamagrostis and other grasses, from Austria, Finland and Sweden.

The use of this epithet for this group of collections on grasses and sedges is a provisional one only. These collections differ from $P$. punctata and $P$. thurgoviana in the lack of discoloration of the substrate, and in the somewhat larger and more acutely pointed ascospores. They have the larger perithecia of $P$. thurgoviana and the yellow-brown spores of $P$. punctata.

There are several described species which must be considered in relation to these grass-inhabiting forms. These are $P$. karstenii ( $P$. arctica Karst.), $P$. punctiformis Niessl and $P$. heleocharidis Karst. $P$. punctiformis, as described by Niessl (1876), differs from these collections only in the rather smaller spores $(23-25 \times 9-11 \mu)$ which are given as chestnut-brown and oblong. His fig. 10, however, shows a fusoid spore, and he says that the spores are strongly constricted at the central septum and not at the other septa, which is the case in most of these collections. Berlese (1900) figures clathrate spores from Niessl's original collection and places this species in Clathrospora. Collection No. 355 is labelled $P$. punctiformis var alpina Rehm and has drawings of a clathrate, seven-septate spore upon the packet. There are some collapsed spores which are narrow- er, in this material, but no clathrate spores were seen. The identity of $P$. punctiformis is still doubtful.

The descriptions of $P$. karstenii $(P$. arctica) and $P$. heleocharidis are very similar, although these species are supposed to be distinct. The original description of $P$. heleocharidis gives very large spores, 45-55 $\times 13-16 \mu$. Berlese (1900), again from type material, gives the spores as $42-48 \times 13$ $15 \mu$. A portion of Karsten's type collection in the Riksmuseum showed a few perithecia but they were all immature. Karsten's Fung. Fenn. No. 882, in the Farlow Herbarium, yielded a few perithecia with asci $80-85 \times 28-31 \mu$ and seven-septate, yellowbrown ascospores with bluntly tapered ends and constrictions at all septa, measuring $34-44 \times 10$ $11 \mu$. The other collections included here differ from this exsiccatus only in the slightly smaller ascospores which are more pointed at the ends and not constricted at the secondary septa. It is possible that varieties on grasses and sedges may be distinguished but more collections are needed for such a decision.

Pleospora tomentosa Wehm. in Lloydia 9: 213. 1946.-This species has also been described by the writer. It differs from the three preceding ones on monocotyledons in the densely tomentose perithecia. The spores (fig. 4) are fusoid, with rather blunt ends and not asymmetric.

Collections: 277, 278 (type), 280; on Castilleja and Rudbeckia, from the Tyrol and $W_{y}$ yoming.

Rehm's collection (277) from the Tyrol has spores which seem to be immature, and rather ir regularly septate, with many septa laid down at an oblique angle, but otherwise as in the species.

Pleospora henningsiana Ruhl., Jahn \& Paul in Verh. Bot. Ver. Brandenburg 43: 105. 1901.Perithecia large, $500-900 \times 300-500 \mu$, scattered, somewhat flattened-spheric, entirely immersed in the bark and visible on the surface as small, circular, flattened or sunken spots, commonly with a raised margin and a central erumpent, papillate ostiole; wall stromatic, $20-100 \mu$ thick, of coarse brown parenchyma.

Asci stout-clavate, thick-walled, base claw-like, $110-160 \times 20-35 \mu$, imbedded in numerous, filiform, interthecial strips.

Spores (fig. 9) biseriate, cylindric-ellipsoid, yellow-brown, seven-septate, straight, somewhat asymmetric, slightly tapered toward one end, both ends rounded, slightly constricted at all septa, vertical walls in several or all central cells, occasionally in the end cells, but laid down separately in each cell and not of the vulgaris type, sometimes with a gelatinous envelope, $39-44 \times 12-14 \mu$.

Collections: 283, 284; on Salix and other dead stems from Germany.

This species is anomalous in many respects. It is placed in this series arbitrarily because of the symmetric septation of the spores. The transverse septa 
are laid down first, however, as in a leptosphaeroid type. The end cells, again, may occasionally have vertical septa. It occurs on woody stems and has the large, thick-walled perithecia of that habitat, but the spores are biseriate in a clavate ascus.

Collection 283 is accompanied by a full description and labelled " $P$. henningsiana W. Ruhl. nov. sp., exple autoris 5/98, ramis emortuis, prope Pankow (Berlin)." Sydow's collection (284) is on Salix from "Schönhausen bei Berlin, 9/4/98, leg. Ruhland." The type is given as on Corylus (?), from Wiedershönhausen, Berlin. The two collections are identical.

The transition from the seven- to the nine-septate condition in the spore, of the general form of that found in $P$. heleocharidis and $P$. tomentosa, is seen in the following species, which often has tertiary septa inserted in the end cells.

Pleospora Pleosphaerioides Wehm. in Lloydia 9: 214. 1946.-This species has been previously described by the writer. The spores (fig. 6) are $32-39 \times 9.5-12.5 \mu$ and of the form found in $P$. heleocharidis and P. tomentosa, being inequilateral, rather tapered at the ends, constricted at the central but not the secondary septa, and red-brown in color. The perithecia differ from those of $P$. tomentosa in being stiffly setose, rather than tomentose.

Collections: 273 (type) on Gilia from Wyoming.

This increase in the number of septa is carried much further in the following species, but the spore form is still similar. The perithecia are of the large type found on woody substrata.

Pleospora moravica (Petr.) comb. nov.- $P$ y. renophora moravica Petr. in Ann. Mycol. 2: 243. 1923.-Perithecia 350-800 $\times 300-600 \mu$, immersed in the bark or wood and then erumpent as a stout papillate ostiole through elliptic; blackened areas of the wood surface, or erumpent on decorticated wood as conic ostioles and flattened perithecia; wall thick, particularly at the sides, $30-120 \mu$, composed of brown to greenish-black parenchyma.

Asci cylindric-clavate, becoming cylindric, thickwalled, particularly at the apex, base claw-like, $135-175 \times 14-21 \mu$, imbedded in numerous filiform interthecial strips.

Spores (fig. 7) biseriate at first then overlapping uniseriate, fusoid-ellipsoid, variable in length, fiveseptate when immature, becoming seven- to elevenseptate by the insertion of vulgaris type septa in the two central, or all the cells, straight or inaequilateral to slightly curved, constricted at the central septum, but not at all or only slightly so at the secondary septa, ends tapered, $23-35 \times 8-10 \mu$.

Collections: 282, 286 (type), 489; on Salix, Salsola, Vitis, from Italy, Moravia and the Near East.

There are placed here, under Petrak's species name a group of collections which have the large perithecia and other characters of the wood-inhabiting forms and which have extremely variable spores. The type collection (286) has immature spores which are five-septate; vulgaris type secondary septa may arise in the two central cells giving seven-septate spores, or in four of the central cells, giving nine-septate spores. Again, secondary transverse, or true vulgaris septation may appear in the end cells, giving rise to an eleven-septate spore. In this variation within the septation of the spore and the large perithecia, this species is similar to $P$. abscondita, which differs only in the more asymmetric character of its spore septation.

Collection No. 282 is accompanied by a descrip. tion and the notation "Pleospora conoidea Rehm sp. nov." This is crossed out and the collection is said to differ from $P$. salsolae in the larger perithecia. Some of the perithecia have short stout spores which are seven-septate and very much like those of $P$. salsolae, except for the lack of vertical septa in the end cells. Other perithecia, however, have longer spores with nine or eleven septa. The spores in collection No. 489 are nearly all seven-septate, but they are obviously immature, and as the perithecial structure is identical with Petrak's species it is included here for the present. It is labelled " $P$. coronata," but it is not that species.

Petrak (1923) states that his species has creeping tomentum-like hyphae on the surface of the perithecia, but neither tomentum nor setae were seen on this material; certainly not sufficient to place it in the genus Pyrenophora, if that genus is recognized.

The following species has a similar spore form, but larger spores, and a septation which is at first definitely leptosphaeroid, but followed by the formation of a vulgaris type of secondary septa in the central cells, as in the preceding species.

Pleospora saponariae (Frag.) comb. nov.Pyrenophora saponariae Frag. in Mem. R. Soc. Española Hist. Nat. 11 : 95. 1919.-Perithecia scattered, $100-150 \mu$ in diameter, membranous, immersed. Asci about $125 \times 35 \mu$.

Spores (fig. 13) biseriate, fusoid-ellipsoid, dark red-brown, almost opaque, five- to eleven-septate, inaequilateral, flattened on one side, symmetric, tapered toward the bluntly rounded ends, no constriction or a very slight one in the middle, primarily five- then seven-septate, with faint vulgaris type secondary septa appearing in two or four of the central cells, resulting in nine- to eleven-septate spore, $48-57 \times 16-18 \mu$.

Collection: 497 (type) on Saponaria from Spain.

This collection is labelled Pyrenophora saponariae. The perithecia are scattered among the fruit bodies of some other fungus, and no setae were seen upon them. The spores, however, are quite distinct. The large size, inaequilateral form and dark color are distinctive. The septation is leptosphaeroid. The three primary septa are laid down first, then the secondary septa in the end cells, and usually tertiary septa in the resulting end cells. These first seven septa are usually distinct. A vul- 
garis type of secondary septation may also occur in two or four of the central cells, but these walls are thinner and less distinct. The species is included here because of the symmetric septation and spore form which are similar to the preceding species.

The following three species differ somewhat from the preceding in their spore form, and are often found on reddish or purplish areas of the stem. The spores have more rounded ends and tend to be more inaequilateral or curved than in the preceeding group. In $P$. minor and $P$. alismatis the spores are also narrowed at the ends and have rather conspicuous constrictions at all septa, whereas in $P$. rubicunda the spores have broader ends and little or no constrictions at all septa.

Pleospora minor sp. nov.-Perithecia $250 \mu$ in diameter, scattered, associated with small reddish spots upon the stem. Asci clavate, base claw-like, 85-130 $\times 14-19 \mu$. Spores (fig. 8) biseriate above, uniseriate below, fusoid-ellipsoid, seven- (rarely eight-) septate, yellow-brown, inaequilateral or slightly curved, symmetric, constricted at all septa, ends bluntly tapered, the two central cells usually with vulgaris type septation, vertical walls in other cells scattered, none in the end cells, 21.4-26.5X $7-7.5 \mu$.

Collections: 276 (type) on grass from England.

This collection $(276)$ is labelled $P$. rubicunda Niessl, but is obviously not that species, although the reddish spots on the stem might suggest a relationship. Only a few perithecia were seen. The spores are of the same form as those of $P$. alismatis but smaller and with fewer septa. They differ from the preceding and following species in being narrower, more strongly constricted at the septa and more strongly curved or inaequilateral.

Pleospora minor sp. nov.--Perithecia $250 \mu$ diametro, dispersa, in maculis rufo-purpureis. Asci clavati, $85-130 \mu$ longi, $14-19 \mu$ crassi, basi unguiculiformes. Sporae sursum biseriatae, deorsum uniseriatae, fusiforme-ellipsoidales, $21.5-26.5 \mu$ longae, $7-7.5 \mu$ crassae, 7 -(interdum $8-$ ) septatae, luteibrunnae, inequilaterales vel curvatae, symmetricae, ad septa constrictae, utrinque late angustate; 2 cellulis centralibus cum "vulgaris" septis praedita; septis verticalibus in cellulis centralibus dispersis, non in cellulis terminalibus.

Specimen typicum (n. 276) vide infra enumeratione locorum. In caulibus graminearum, ex Anglia.

Pleospora alismatis E. \& E. in Jour. Mycol. 8: 16. 1902.--Perithecia $300-500 \times 250-400 \mu$, somewhat flattened, globose to hemispheric, appearing on the surface as rather widely scattered, large, circular to elliptic, black spots, with a central erumpent, papillate ostiole; wall consisting of a thin outer layer of small-celled, brown parenchyma, 20$30 \mu$ thick and an inner indefinite layer of hyaline parenchyma.

Asci clavate to cylindric-clavate, wall slightly thickened, base claw-like, imbedded in numerous, filiform, interthecial strips, $85-100 \quad(160) \times 12.5-$ $18 \mu$.

Spores (fig. 11) biseriate, becoming uniseriate, fusoid to fusoid-ellipsoid, mostly nine-septate, yellow-brown, symmetric, ends rounded or bluntly tapered, inaequilateral or curved, slightly constricted at all septa, two central cells usually with vulgaris type septa, remaining cells with or without vertical walls, no vertical septa in the end cells, $26-30(33) \times 7-9.5 \mu$.

Collection: 285 (type) on Alisma plantago from S. Dakota.

The original description of this species gives the spores $(22-27 \times 10-12(15) \mu)$ as somewhat shorter and broader, but is otherwise identical with the type material seen. The spores have the form of those of $P$. minor, on grass, but have two extra, tertiary septa in the end cells. The spores of $P$. thurgo viana also approach those of this species in form. but have blunter ends.

Pleospora Rubicunda Niessl in Verhand. Naturf. Ver. Brünn 14: 191. 1876.-Perithecia 250-400X $200-300 \mu$, globose or. somewhat flattened, formed beneath the surface on purplish-red discolored areas of the stem, soon erumpent as stout papillate ostioles; walls $20-30 \mu$ thick, of flattened black parenchyma.

Asci numerous, clavate to cylindric-clavate. thickwalled and with a claw-like base, $90-160 \times 12-25 \mu$, imbedded between filiform, interthecial strips.

Spores (fig. 10) biseriate to overlapping uniseriate, stout fusoid-ellipsoid, (seven-) usually nine- or eleven-septate, yellow-brown to red-brown, symmetric, inaequilateral or curved, constricted at the central septum, but usually not so at the secondary septa, primarily seven-septate with vulgaris-like septa inserted in two to four of the central cells, no vertical walls in the end cells, $23-39 \times 8-13 \mu$.

Collections 287, 288, 289, 290, 346; on Aconitum, Brachypodium and other stems, from Central Europe.

Three of these collections $(287,289,290)$ are given by Rehm as Pleospora anthyllidis var. aconiti, but the spores are "cymbiform and 10-11 septate" as in $P$. rubicunda, not "ovate oblong, 13-15 septate," as in $P$. anthyllidis. All of these collections are on purplish-red spots, as given by Niessl for $P$. rubicunda. No. 346 has spores with a somewhat variable septation and lighter brown color, approaching the variety americana. The spores of this species have more broadly rounded ends and less constriction at the septa than those of $P$. alismatis.

Var. americana var. nov.-Perithecia as in the species, discoloration of substrate pinkish-purple or dark reddish-brown. Spores (fig. 12) $30-38 \times$ $11-15 \mu$, light yellow-brown, slightly or not at all constricted, septation irregular, with tertiary septa successively laid down and the spores, therefore, from seven- to eleven-septate, sometimes asym- 
metrically so, with three septa above and five below the primary central septum.

Collections: 525, 526 (type) ; on Potentilla and Pedicularis, from Washington.

This variety is erected for two collections from Mt. Rainier National Park. Their spores have the same form as in the species, but may be somewhat more strongly constricted and are lighter, yellowbrown. Their septation arises in the same way as in the species, a secondary and tertiary transverse septum arising in each primary end cell, and vulgaris type septa forming in the four central cells, but these vulgaris type septa are tardily and successively formed and spores can be found with seven-, nine- or eleven-septa, whereas in European collections all eleven septa appear early and simultaneously. In this variety the septation may also be irregular or even asymmetric, or with transverse septa which do not extend completely across the spore. One collection shows a purple-red the other a red-brown discoloration.

Var. americana var. nov.-Perithecia ut in species. Asci clavati, $140-180 \mu$ longi, $16-26 \mu$ crassi. Sporae $30-38 \mu$ longae, $11-15 \mu$ crassae, pallide luteibrunneae, non vel paululo constrictae, 7 - vel 11-, irregulariter et saepe asymmetrice-septatae.

Specimen typicum (n. 526) vide infra enumeratione locorum. In caulibus Pedicularis latifoliae, in republica Washingtonensi.

Collections cited.-271. Pleospora thurgoviana Weg. on Typha latifolia, Frauenfeld, Feb. 23, 1896, leg. Wegelin. (Riksmuseet, ex Herb. Rehm.) (Type?).-272. P. punctata Wehm. on Scirpus validus, Elk Refuge, Jackson, Wyo., July 1, 1940 (Wehm. Herb. No. 1071) (Type) -273. P. pleosphaerioides Wehm. on Gilia watsoni, south of Teton Pass, Jackson, Wyo., July 11, 1940 (Wehm. Herb. No. 1118a) (Type).-276. P. rubicunda Niessl on grass, Lynn, Anglia, leg. C. B. Plowright, 1878. (Riksmuseet, ex Herb. Sydow) (Type of $P$. minor). 277. P. hispida Niessl on stems, Moraine des Sulden Gletscher, July 1889, leg. Rehm. (Riksmuseet, ex Herb. Rehm.) -_278. P. tomentosa Wehm. on Rudbeckia occidentalis, Teton Pass, Jackson, Wyo., July 11, 1940 (Wehm. Herb. No. 1108) ('Type).--280. P. tomentosa Wehm. on Castilleja linearifolia, Hoback-Snake river junction, Wyo., July 15, 1940. (Wehm. Herb. No. 1159a).-282. P. concoidea Rehm., inedit, on Salsola rich. teri, Buchara prope St. Faral (?), Sept. 1911, leg. Andrssow. (Riksmuseet, ex Herb. Rehm. No. 242).-283. $P$. henningsiana Ruhl. on Salix, Park von Schönhausen bei
Berlin, Sept. 4, 1898, leg. W. Ruhland. (Riksmuseet, ex Herb. Sydow.) -284. P. henningsiana Ruhl. on stems, Pankow (Berlin), May 1898, with desc. (Riksmuseet, ex Herb. Sydow) (Type).-285. P. alismatis E. \& E. on Alisma plantago, Tacoma Park, S. Dakota, Feb. 1898, leg Griffiths. (N.Y.B.G., Griff. W. Amer. Fung. 308) (Type).-286. Pyrenophora moravica Petr. on Salix, Mähr-Weisskirchen: Chorin, Aug. 25, 1922, leg. Petrak. (Riksmuseet, Petr. Fl. Boh. \& Mor. 1696) (Type).-287. Pleospora anthyllidis Awd. \& Niessl, var. aconiti on Aconitum, Tyrol, Sept. 1905, leg. Rehm. (Riksmuseet, ex Herb. Rehm.).-288. P. rubicunda Neissl on stems, bei Neufriedenheim, 1903, leg. Rehn. (Riksmuseet, $\odot$ X Herb. Rehm.).-289. P. anthyllidis Awd. \& Niessl. var. aconiti Rehm. on Aconitum napellus, Taschach Gletscher, Tyrol, Aug., 1875. (Riksmuseet, ex Herb. Rehm.).--290. P. anthyllidis var. aconti Rehm. on Aconitum, 1885, leg. Prof. Linhart. (Riksmuseet, ex Herb. Rehm.).-330. Undetermined, on Calamagrostis lanceolata, Sueciae: Jemtlandiae prope viam inter Storlien et Storvallen, July 31, 1932, A. G. Eliasson. (Riksmuseet: Fl. Suec.). 346. Undetermined, on Brachypodium velutina, Klingenteich im Mainecker, May 24, 1909, Ieg. A. Ade. (Riksmuseet) - -353. Undetermined, on Aira flexuosa, Torne, Lappmark, Vassilaure, Aug. 16, 1903, leg. T. Vestergren. (Riksmuseet: Fl. Suec.).-355. Clathrospora punctiformis var. alpina Rehm., Tyrol, Sept. 1905, leg. Rehm. (Riksmuseet, ex Herb. Rehm.).-489. Pleospora coronata Niessl on Vitis sp., Italia: Conegliano, July 1879. (La Plata Mus. No. 7186).-497. Pyrenophora saponariae Frag. on Saponaria caespitosa, prope Montree d'Ares (Lerida), March, 1899, leg. Font. Quer. (Herb. Jard. Bot. Madrid: Fung. No. 2920) (Type) inedit. (?).-525 Pleospora rubicunda var. americana Wehm. on Potentilla flabbelifolia, Yakima Park, Mt. Rainier, Wash., 6,400 ft., Aug. 18, 1948, leg. E. G. Simmons No. 195la (Wehm. Herb ) - 526. $P$. rubicunda var. americana Wehm. on Pedicularis latifolia, Mt. Rainier, Wash. 6,000 ft., leg. E. G. Simmons No. 1960, Aug. 17, 1948. (Wehm. Herb.) (Type of var.) -669. P. heleocharidis Karst. on Heleocharis palustris, Runsala, June. (Farl. Herb., Karst. Fung. Fenn. 882) (Type).

\section{SUMMARY}

This paper concludes the discussion of the genus Pleospora by considering the relationships of those species having spores with more than five transverse septa and with a symmetric, vulgaris type of septation. One new species, Pleospora minor, and one new variety, Pleospora rubicunda Niessl var. americana, are described.

$$
\begin{aligned}
& \text { Department of Botany, } \\
& \text { University of Michigan, } \\
& \text { Ann Arbor, Michigan }
\end{aligned}
$$

\section{LITERATURE CITED}

Btrlese, A. N. 1900. Icones Fungorum omnium cognitorum ad usum Sylloges Saccardianae accomodates. Vol. 2. Typis Seminarii. Patavii.

Niessl, G. von. 1876. Notizen über neue und kritische Pyrenomyceten. Vehr. Naturf. Ver. Brünn. 14: 165217.
Petrak, F. 1923. Mykologische Notizen. VI. Ann. Mycol. 2I: $182-335$

Wenmeyer, L. E. 1952a. Studies in the genus Pleospora. II. Lloydia. In press.

_.. 1952b. Studies in the genus Pleospora. V. In press. 